\title{
Probability of Default Model to Estimate Ex Ante Credit Risk ${ }^{1}$
}

\author{
Anna Burova, Bank of Russia \\ burovaab@mail.cbr.ru \\ Henry Penikas, Bank of Russia, Higher School of Economics, \\ Lebedev Physics Institute \\ penikasgi@mail.cbr.ru \\ Svetlana Popova, Bank of Russia \\ popovasv@mail.cbr.ru
}

\begin{abstract}
A genuine measure of ex ante credit risk links borrower's financial position with the odds of default. Comprehension of a borrower's financial position is proxied by the derivatives of its filled financial statements, i.e. financial ratios. We identify statistically significant relationships between shortlisted financial ratios and subsequent default events and develop a probability of default (PD) model that assesses the likelihood of a borrower going into delinquency at a one year horizon. We compare the PD model constructed against alternative measures of ex ante credit risk that are widely used in related literature on bank risk taking, i.e. credit quality groups (prudential reserve ratios) assigned to creditors by banks and the credit spreads in interest rates. We find that the PD model predicts default events more accurately at a horizon of one year compared to prudential reserve rates. We conclude that the measure of ex ante credit risk developed is feasible for estimating risk-taking behaviour by banks and analysing shifts in portfolio composition.
\end{abstract}

Keywords: ex ante probability

of default, corporate credit, credit registry, probability of default model, credit quality groups, credit spreads

JEL Codes: E44, E51, E52, E58, G21, G28
Citation: Burova, A., Penikas, H. and Popova, S. (2021). Probability of Default Model to Estimate Ex Ante Credit Risk. Russian Journal of Money and Finance, 80(3), pp. 49-72.

doi: $10.31477 /$ rjmf.202103.49

\footnotetext{
${ }^{1}$ We are grateful to Alexey Ponomarenko and Andrey Sinyakov for their valuable suggestions and comments, to Natalia Turdyeva and Yulia Ushakova for their valuable assistance, and to colleagues from the workshop held at the Bank of Russia in May 2020. We acknowledge the two anonymous reviewers who helped greatly improve our paper. The views expressed in this paper are solely those of the authors and do not necessarily reflect the official position of the Bank of Russia. The Bank of Russia shall not be responsible for the content of this report.
} 


\section{Introduction}

Central banks pay considerable attention to risk-taking by commercial banks. In order to monitor risk taking, one needs a model evaluating the riskiness of a bank's borrowers. Conventionally, researchers have looked at a bank's capital adequacy ratio as an indicator of risk-taking (Cecchetti and Li, 2005; Borio and Zhu, 2008; Bruno and Shin, 2012): the lower the ratio is the more risk the bank has taken. The evaluation model developed should act ex ante, i.e. be unaware of a borrower's future performance. If we have such a model for creditworthiness evaluation, we can further study the determinants of bank risk taking. The natural solution is to use a probability of default (PD) model. Though there are many public studies on the topic of the development of PD models, to the best of our knowledge none actually develops the one that deals with delinquency and not outright bankruptcy. The reason for this is the constraint on accessible data. Delinquency data from credit bureaus is usually not publicly available, while bankruptcy information is public.

Thus, we are the first to offer a true PD model, using supervisory confidential delinquency data from Russian credit bureaus on corporate borrowers from 2012 to 2018. The time evolution of the default rate (90 days past due in our case) can be seen below in Figure 1. The default rate is the fraction of companies which defaulted in a given year, out of the companies which did not default in the previous year.

Figure 1. Default rate at the economy level

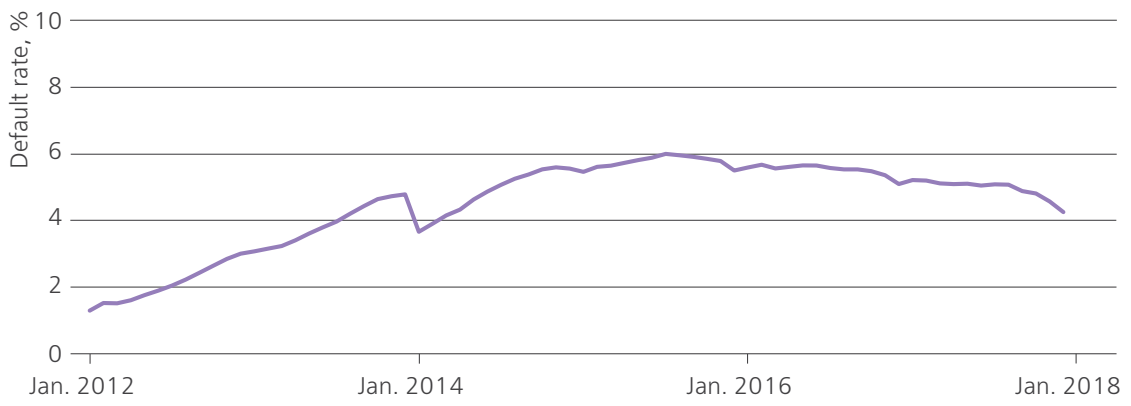

Source: authors' calculations

Our research objective is to investigate the value of the new and matched data for Russian corporate borrowers using one of the common models. By 'value', we mean the improvement of default prediction as judged by F1 score (see formula (2) in Section 3.3). When we say 'new', we mean delinquency information for each company from Russian credit bureaus, which has never previously been considered in academic research. Matched data is a combination of SPARK financial reporting data and confidential Bank of Russia data on the entire pool of loans offered to Russian corporate borrowers. Such data has never been used by academic 
researchers in Russia for the development of PD models. The common model we refer to is the Moody's model concerning Russian corporate borrowers developed by Dwyer et al. (2010). Technical details for it are available in Korableva (2011). We could have chosen alternative models from Beaver (1966), Altman (1968), Ermolova and Penikas (2017), or Mogilat (2019). However, we wished to benchmark against this particular Moody's model due to its simplicity.

Our principal finding is that prudential provision rates are much less helpful in predicting default than the estimates from our model. Thus, our model is the first to call for the revision of the prudential provision rate and/or the establishment of a common PD model for risk-management outsourcing, as is done in the US for the smallest banks. Penikas (2013) (see also the references therein) is the first to broadly discuss the advantages of such a common PD model over those used individually by banks.

Our contribution to the existing literature is as follows.

1) We use a novel dataset that allows us to introduce the prudentially compliant definition of default of 90 days past due used in the Basel II Internal-Ratings-Based (IRB) approach. Korableva (2011) and Ermolova and Penikas (2017) use the same definition of default. However, Korableva (2011) uses an outdated sample from 2002-2009, while we use recent data from 2017-2020. Ermolova and Penikas (2017) study only a subsample of the largest borrowers. Mogilat (2019) covers the same data by the available firm identifiers (and definitely not by time coverage) as we do (only earlier sample), but she uses a non-compliant definition of default, as she looks at cases of bankruptcy only. We may briefly note that bankruptcies are a three-to-five-year lagging indicator of default. That is, Russian companies that go bankrupt do so an average of three to five years after first missing due payments. This is why banking credit policies focus on capturing the very first delay in payment, and it is why a default indicator based on a 90-days-past-due (DPD) definition of default is quite different from an indicator based on bankruptcy. It is, thus, novel to study a $90 \mathrm{DPD}$ definition of default, rather than bankruptcies.

2) We confirm that using delinquency data helps to improve default predictions for Russian data compared to prudential reserve ratios. Neither Russian researchers, such as Korableva (2011), Ermolova and Penikas (2017), or Mogilat (2019), nor foreign researchers, such as Dell'Ariccia et al. (2017) or Paligorova and Santos (2017), have made such comparisons using Russian data.

3) The methods we apply are interpretable and reproducible, unlike the advanced machine learning techniques used, for example, by Shibitov and Mamedli (2019).

To guide the reader through the model development process, we briefly review existing literature in Section 2. We explain our methodology in Section 3. 
We present the necessary data in Section 4. Our empirical findings are given in Section 5. Section 6 is our conclusion, with policy implications.

\section{Literature review}

PD models represent a vast research field. Corporate borrowers are the most frequently studied. There are models for SMEs abroad, such as those given by Altman and Sabato (2003), Luppi et al. (2007), Pompe and Bilderbeek (2005), Fantazzini and Figini (2009), Vozzella and Gabbi (2010), Andrikopoulos and Khorasgani (2018), and Gupta et al. (2018). There are models for Russian corporates, such as those presented by Dwyer et al. (2010), Totmyanina (2014), Surzhko (2014), Karminskiy (2015, pp. 217-222), Ermolova and Penikas (2017), and Mogilat $(2015,2019)$.

We highlight the novelty of our approach in Table 1 . Our research is unique in that it uses delinquency as the dependent variable with respect to the entire population of Russian enterprises. Previous works have either looked at the same population but used a bankruptcy indicator (Mogilat, 2019) or have studied a delinquency indicator but looked only at the subset of the largest enterprises (Ermolova and Penikas, 2017).

Table 1. Comparing our study to previous research

\begin{tabular}{l|ll} 
Data sample & Dependent variable & \\
\cline { 2 - 3 } & Bankruptcy & Default (90 DPD) \\
\hline All enterprises & Mogilat (2019) & This paper \\
\hline Large enterprises with publicly traded bonds & n/a & Ermolova and Penikas (2017) \\
\hline Source: compiled by the authors & &
\end{tabular}

To validate the feasibility of our measure, we want to compare its PD prediction with the alternative measures of ex ante credit risk extensively used in the literature (but not for PD modelling).

1) Credit quality groups (CQG), or prudential reserve ratios, assigned by banks to each borrower at the time of loan issuance for the purpose of meeting capital regulation requirements. Dell'Ariccia et al. (2017) use confidential data on individual US banks' loan ratings from the Federal Reserve's Survey of Terms of Business Lending (STBL) and find that there is small, but economically meaningful co-dependence of the risk taking proxy by banks and the aggregate level of the credit quality groups. Another example of the application of internal ratings can be found in Ioannidou and Penas (2010). The most recent example known to us is Miteski et al. (2018) that uses internal ratings and credit registry data for Macedonia.

2) Credit spreads (CS) in interest rates, e.g. the spread between the credit rate and the key policy rate or the money market rate (the transfer curve). This is considered to be banks' mark up over the minimum funding costs 
proxied by market interest rates. Paligorova and Santos (2017) study how monetary policy affects the spread over LIBOR of loan rates charged to borrowers with and without investment grade and find that higher spread is associated with larger values of the bank risk-taking proxy indicators. Another example of the application of credit spreads in interest rates is Delis et al. (2017). The authors construct a comprehensive dataset based on the US credit registries and use the loan interest rate spread over LIBOR as an ex ante measure of credit risk, and find evidence supporting the existence of a risk-taking channel, especially before the global financial crisis, i.e. the lower the policy rate is or the larger the spread is, the banks are prone to take more risks both in absolute terms and in relative ones. This means they tend to both expand the loan book and the average riskiness (risk-weight) of the loans in the book.

\section{Methodology}

In general, we follow the process of PD model development documented in detail in our previous works (Lozinskaia et al., 2017; Ermolova and Penikas, 2017) for world shipping companies and large Russian corporations issuing publicly traded bonds. They use the probit and logit models originally proposed by Bliss (1934) and Berskon (1944), respectively. Below we explain the methodology by describing the definition of default, the model specification, and the alternative benchmarks used.

\subsection{Definition of default}

The development of a PD model begins with the definition of the dependent variable, namely the definition of default. We use payment overdue by more than 90 days, in accordance with the Basel II (III) Internal ratings-based (IRB) methodology (Basel Committee on Banking Supervision, 2017). We do not account for the unlikely to pay (UTP) criteria, as those are not readily available for the entire set of borrowers (Basel Committee on Banking Supervision, 2006, p. 100, par. 453). We define a default event as an instance of a payment overdue by more than 90 days or an instance in which a firm is officially liquidated according to information from the SPARK database. ${ }^{2}$ We assign a default mark to a business entity which has defaulted in the month in which the default event took place. We then expand the default mark over the previous 11 months to fix the year in which the entity has defaulted. We do not exclude defaulted entities from the remaining observations. We perform a 12-month backward shift of default marks to match defaults in the

\footnotetext{
2 The SPARK database contains financial (quantitative) and non-financial (qualitative) information on the business entities operating in Russia. The database is available from the Interfax News Group at https://spark-interfax.com
} 
next year with the current-year financial characteristics of the firms. We do this in order to train the model to estimate the probability of default at a horizon of one year using the most recent financial information on the borrowing entities. See Figure 2 for an illustration. We will demonstrate this methodology observationwise in Section 4.1, see Table 3.

Figure 2. Time scheme of default mark assignment and treatment of financial statements (FS)

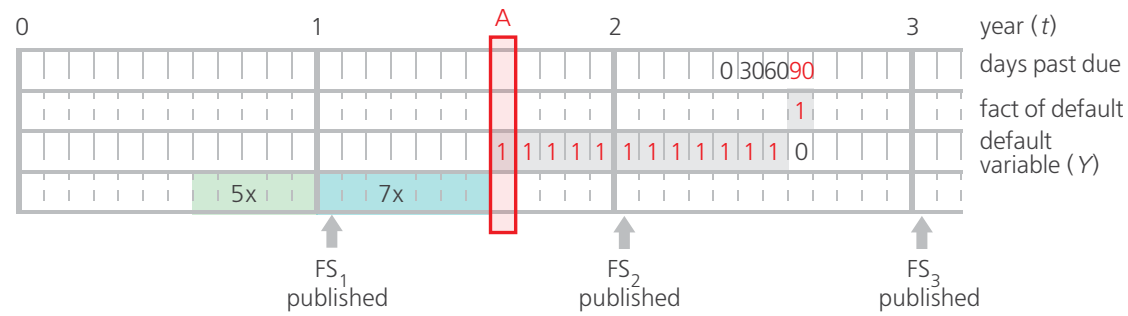

Source: compiled by the authors

Table 2. Observations at industry level

\begin{tabular}{ll} 
Industry & Number of firm-month observations \\
\hline Forestry and Agriculture & 573,643 \\
\hline Mining & 61,367 \\
\hline Manufacturing & $1,603,842$ \\
\hline Utilities & 167,558 \\
\hline Construction & $1,466,147$ \\
\hline Wholesale and Retail & $5,215,239$ \\
\hline Hotels and Restaurants & 322,813 \\
\hline Transportation & 713,095 \\
\hline Other sectors & $2,218,266$ \\
\hline Information not available & 7,807 \\
\hline Total & $12,349,777$ \\
\hline
\end{tabular}

Source: compiled by the authors

An entity receives a default mark when it has defaulted. For an entity to have its default mark removed, it must continue to exist (confirmed via the SPARK database) for the 12 months and do so with no periods in which it has debt overdue by more than 90 days. We calculate the default rate with monthly frequency for Russian corporate borrowers using data from Russian credit bureaus for 2012-2018. It is calculated as the proportion of firms that default in the 12 months following the month of observation, represented as a percentage of the total number of firms observed in that period. We observe an increase in the default rate during 2014-2016, which was a turbulent period for the Russian economy (see Figure 1 in Section 1). As the developed countries have sovereign credit ratings higher than that of Russia (BBB-), the default rate observed for Russian companies exceeds those observed in developed countries. 
To address the heterogeneity of the operating and financial conditions, we classify borrowing entities into nine aggregate industries. See online version of this paper, Appendix A for the detailed compositions of the industries. The number of observations within each industry is presented in Table 2 .

To address the heterogeneity of the borrowing conditions, we classify the entities into high-leverage and low-leverage classes based on the median value of leverage for all observations. Leverage is calculated as the sum of long-term debt and short-term debt normalised by total assets, i.e. it is equal to $\left(1-L E V_{-} E Q\right)$, where $L E V_{-} E Q$ is defined in Table $\mathrm{B} 1$ in the Appendix $\mathrm{B}$. This definition of leverage is used in work by the Bank of Japan (2019). See Figure 3 for a graphical representation of the industry-level default rates.

\subsection{PD model specification}

To evaluate PD, we use a probit model (Cameron and Trivedi, 2010, p. 460), a conventional binary choice model where the dependent variable $Y$ reflects the occurrence of default. It equals one when default occurs and zero otherwise. $X$ is a vector of the independent variables. $\beta$ is a vector of the coefficients (model parameters). We estimate $\beta$ using the maximum likelihood procedure. The model specification is

$$
P(Y=1 \mid X)=\Phi\left(X^{\prime} \beta\right),
$$

where $\Phi(\cdot)$ is Gaussian cumulative density function.

When the model is fit to the data, we obtain a prediction of the probability of default, $\widehat{P D} \in[0 ; 1]$.

We refer to the model specification introduced by Moody's Analytics' RiskCalc that is built and tested with a dataset of Russian companies. The model specification includes only interpretable methods such as ordinary least squares (OLS) and probit and does not include any non-interpretable methods like the ones used in machine learning, e.g. ensemble methods (Random Forests) or deep-learning neural networks like in Shibitov and Mamedli (2019). The estimated regression residuals are presented in Table 9. The variables and their transformations are chosen to avoid multicollinearity, heteroskedasticity, and non-Gaussian distribution to the extent feasible for real-world data. We do not run any adjustment for through-the-cycle ${ }^{3}$ (TTC) PD, as such a procedure in our opinion has no theoretical grounding (for explanation see Penikas, 2020b), although it is often used in practice and is often referred to, for example, as by Ozdemir and Miu

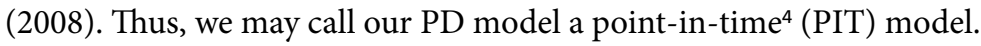

\footnotetext{
3 TTC models try to exclude the common component induced by the business cycle from all the individual PDs.

${ }^{4}$ PIT models do not make business cycle adjustments, in contrast with TTC.
} 
Figure 3. Default rate by industry and leverage level

\section{Construction}

\section{High leverage}

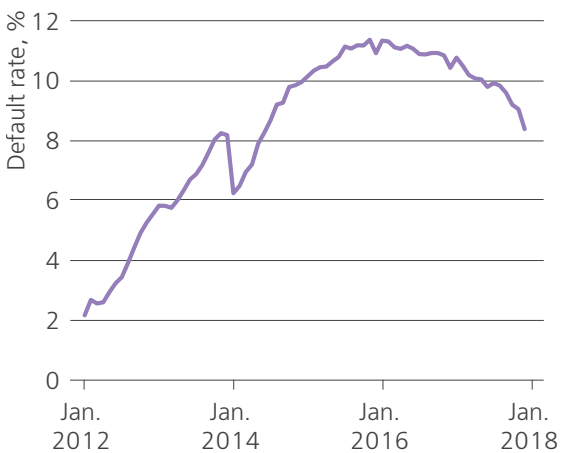

Forestry and Agriculture

High leverage

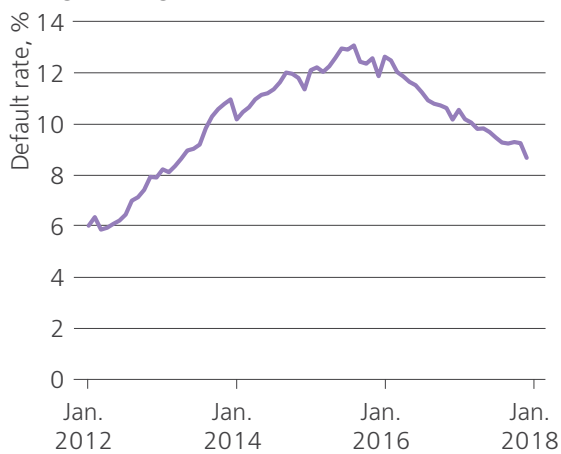

\section{Low leverage}

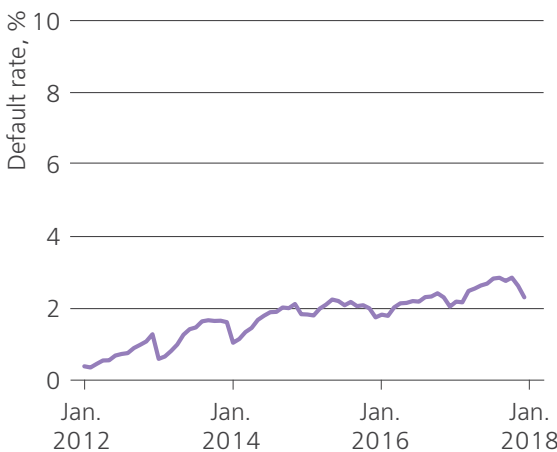

Low leverage

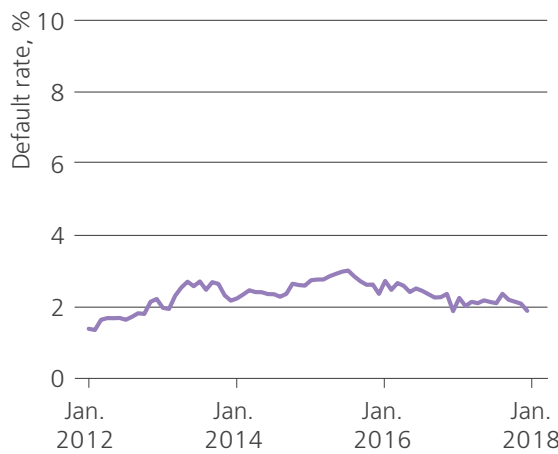

Hotels and Restaurants
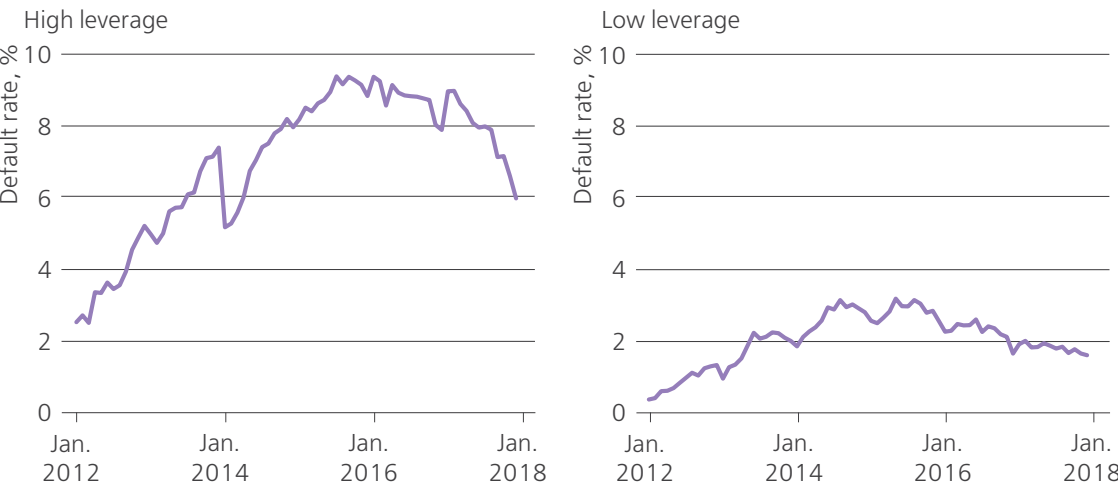

Figure 3 continued on p. 57 


\section{Continuation, Figure 3 starts on p. 56}

Manufacturing

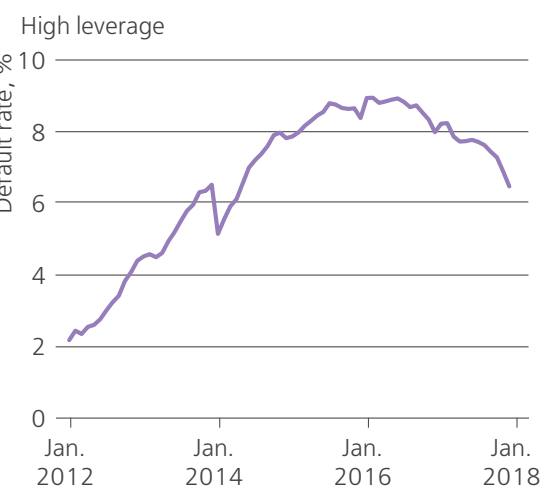

Mining

High leverage

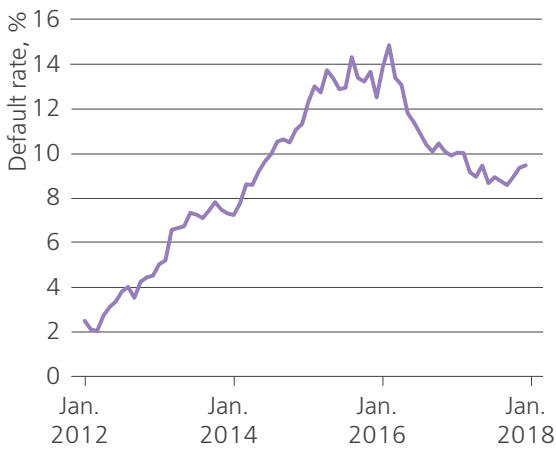

Other sectors

High leverage

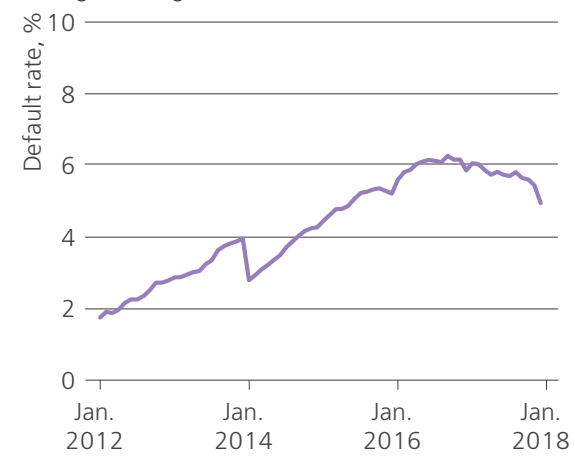

\section{Low leverage}

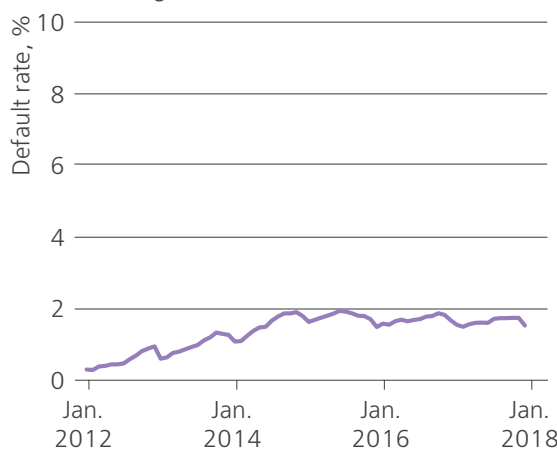

Low leverage

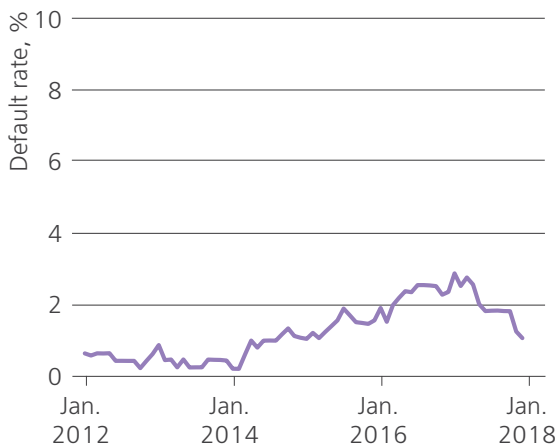

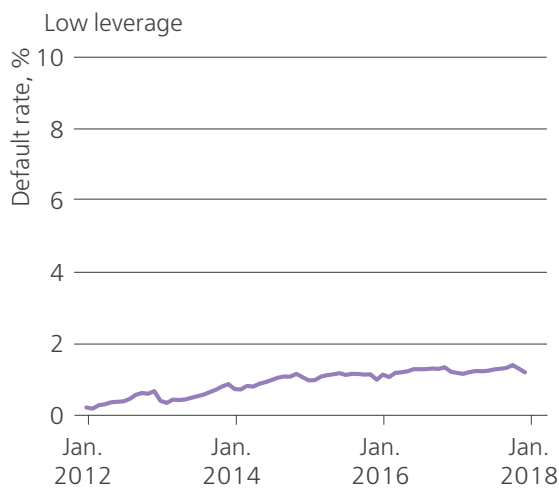

Figure 3 continued on p. 58 
Continuation, Figure 3 starts on p. 56

Transportation

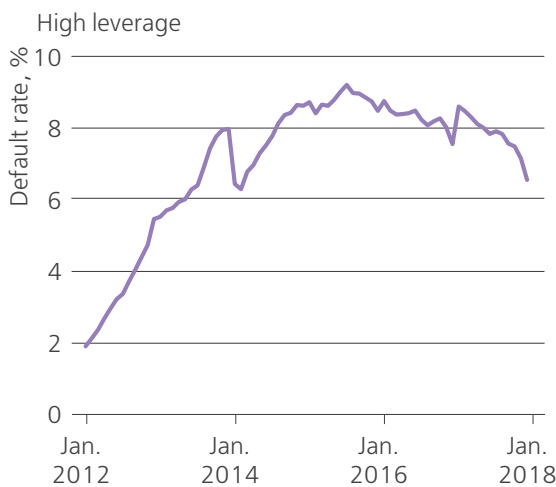

Utilities

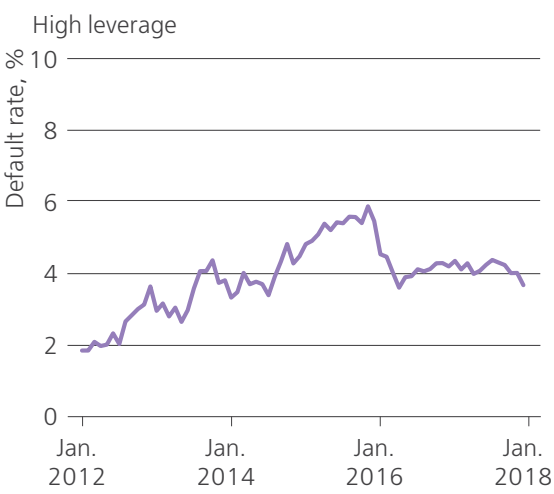

Wholesale and Retail Trade

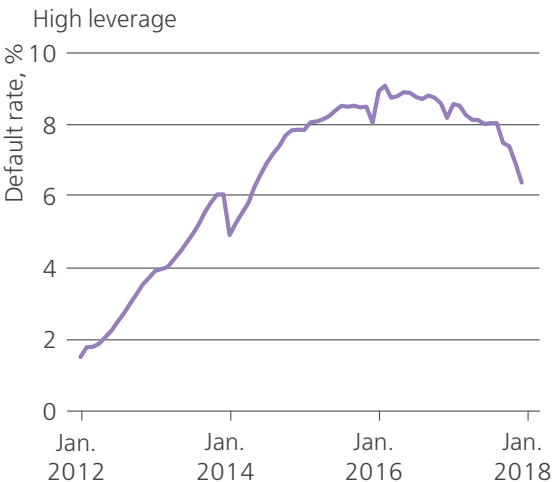

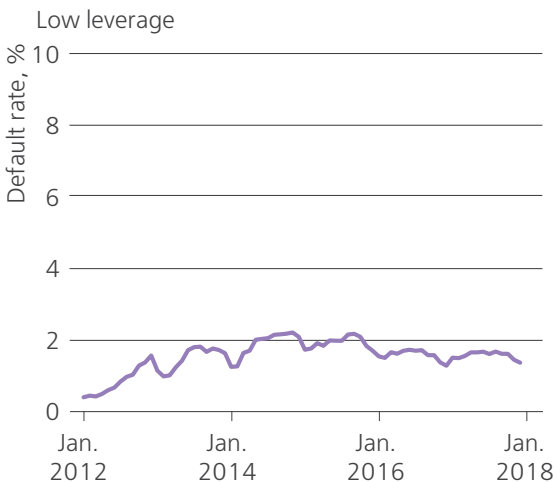
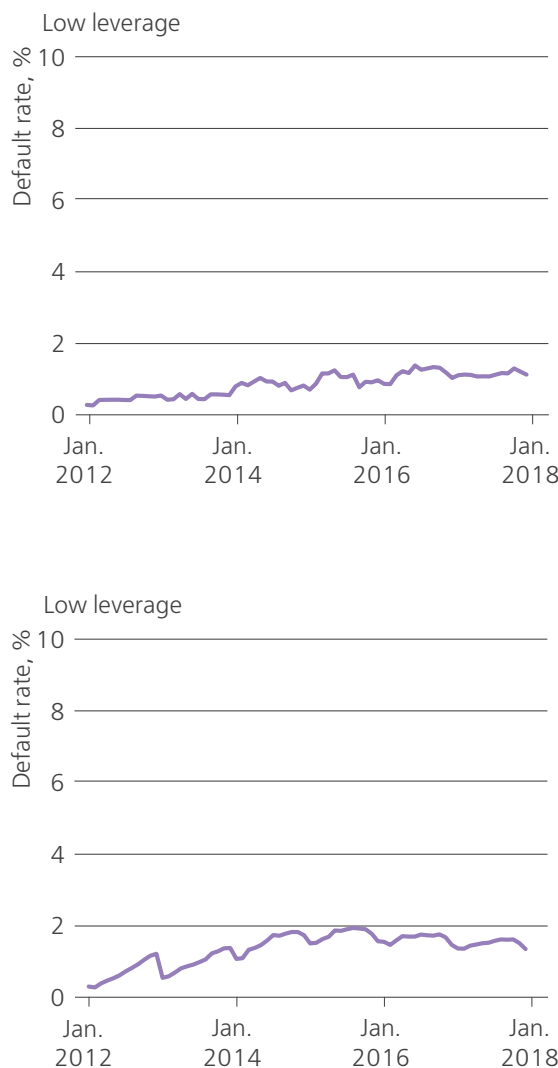

Source: authors' calculations 
When we apply our model in pseudo-real time, that is, when we want to estimate the probability of default at a horizon of one year for newly issued loans comprising the actual portfolio of a bank, we want to use the most recent financial information about the borrower. This way we are confident that we can obtain an up-to-date status estimate. For new loans, we use the most recent financial statement in this step. However, there are cases in which the available financial data lags far behind the estimation date.

\subsection{Validation of the model}

We train the model on a randomly selected $80 \%$ of the dataset and test the model on a remaining $20 \%$ subset of loans. We implement validation procedures based on correspondence analysis, that is, we benchmark the actual default marks against those predicted by the model. We use the F1 score as a metric for the performance of the model, based on the benefits discussed by Shibitov and Mamedli (2019) and in references therein:

$$
F 1=\frac{2 T P}{2 T P+F P+F N},
$$

where TP is the number of observations correctly classified as defaults, FP is the number of observations incorrectly classified as defaults, and $F N$ is the number of observations incorrectly classified as non-defaults.

The F1 score depends on the chosen threshold level. Values of predicted default probability in excess of the threshold correspond to discrete default events. Otherwise, the model signals the absence of a default event. We use thresholds of 0.01-0.5 to identify the level at which the F1 score is highest. We compare three PD model specifications: Model 1 as formulated by Moody's with the set of independent variables and without the control variables for industry or debt level; Model 2 with industry and leverage level controls; and Model 3 with triple interaction terms. Figure 6 shows the evolution of the F1 score depending on the threshold and model specification.

\section{Data}

Detailed information on defaults at the loan level is usually unavailable. In that case, a set of assumptions should be imposed, either backed up by professional judgement or based on generally accepted practices. To overcome the subjectivity of assumptions, we construct a comprehensive micro-level database comprised of firm-level financial information (both quantitative and qualitative, extracted from annual reports and financial statements), firm-bankloan-level information on new loans issued (extracted from credit registries), 
and the firm-bank level information on defaults (extracted from credit history bureau data). The data spans from January 2017 to December 2019.

We define a default event as an instance of a payment's being overdue by more than 90 days or an instance in which a firm is officially liquidated according to information from the SPARK database. We see significant sectoral differences in the relationship between the independent variables and default rates in Figure 3.

The model specification includes firm-level public financial information available from Rosstat and statistics on defaults available from an aggregate comprised of default information from the three credit history bureaus operating in Russia. We use firm-level monthly data on defaults and annual financial information that is translated into monthly data (see Table 3 for the composition of the dataset).

'Default mark assigned' is an extension of 'Entities with loans overdue by more than 90 days'. A company may be 120 days past due (DPD) in one month, but without an entry of delinquency in the previous month. Nevertheless, if it is 120 DPD in one month, it was 90 DPD the previous month. Thus, in row 4, we assign default marks by this logic when we restore the missing delinquency registries.

The category in row 5, 'Default mark 12m backward shift (defaults of next year matched with firm IDs in current year)' leads to a loss of observations. This is a typical situation in the use of lagged variables. It implies a reduction in the dataset. And so does the outlier censoring in row 6.

Table 3. Dataset composition and identification of defaults

\begin{tabular}{llll} 
No. & Operation applied & $\begin{array}{l}\text { Number of } \\
\text { observations }\end{array}$ & Number of defaults \\
\hline 1 & Dataset initialisation & $16,114,889$ & \\
\hline 2 & Entities with loans overdue by more than 90 days & & 535,575 \\
\hline 3 & Entities liquidated (identified from SPARK database) & & 2,509 \\
\hline 4 & Default mark assigned & & 134,481 \\
\hline 5 & $\begin{array}{l}\text { Default mark } 12 \mathrm{~m} \text { backward shift (defaults } \\
\text { of next year matched with firm IDs in current year) }\end{array}$ & $(3,095,820)$ & $(17,336)$ \\
\hline 6 & Censored outliers at $0.5 \%$ and $99.5 \%$ & $(669,292)$ & $(44,686)$ \\
\hline 7 & Total & $\mathbf{1 2 , 3 4 9 , 7 7 7}$ & $\mathbf{6 1 0 , 5 4 3}$ \\
\hline & & $7=1+5+6$ & $7=2+3+4+5+6$ \\
\hline
\end{tabular}

Source: compiled by the authors

\subsection{Independent variables}

We proceed with the set of independent variables. The list consists of balance sheet and income statement elements, as well as their derivatives, i.e. financial ratios. We calculate financial ratios based on the information available from the financial statements and annual reports for the 2011-2018 time period. For definitions of the financial ratios, see Table B1 and Table B2 in Appendix B. 
For our analysis, we use monthly data constructed from annual financial statements. We assign each financial statement (FS) a weight proportional to the number of months spent in the corresponding financial year, thus:

$$
F S_{\text {month } N \text { year } T}=\frac{N}{12} \times F S_{T}+\frac{12-N}{12} \times F S_{T-1} .
$$

The initial list of independent variables corresponds to those in the PD model using the methodology of Moody's RiskCalc v3.1.

Let us assume that we have an instance of a firm's being 90 days past due in month 8 of year 3 (See Figure 2 in Section 3.1). Following the identification of a default event, we extend the default mark backward for 12 months. Thus, at $A$ in Figure 2, we have $Y(A)=1$, meaning that a default mark is present after the 7 th month of year 2 (future event). In order to get monthly firm-level financial data for $\mathrm{PD}$ analysis, we construct the proxy for an annualized monthly financial statement as a weighted average proportional to the number of months spent in each of the corresponding financial years:

$$
X(A)=\frac{5}{12} \times F S_{1}+\frac{7}{12} \times F S_{2} .
$$

Here, financial statement $F S_{2}$ is past information for the event of default. In this construction, we do not use future information when we estimate probability of default.

The ratios selected characterise the performance of entities in terms of activity, solvency, growth, leverage, liquidity, and profitability, see as described by Korableva (2011). See Table B1 in Appendix B for a detailed list of the independent variables and their derivations.

We do not exclude entities with missing values in their financial statements from the dataset. We assign the mean values for those independent $X$ variables entering the model in the event that they are missing. We censor the outliers in the 1 st and 99th percentiles.

In Table B3 (see Appendix B), we report descriptive statistics for the dataset over two separate groups: defaulting firms and non-defaulting firms. An overview of the descriptive statistics shows that there are differences between defaulting and non-defaulting firms. This fact supports our hypothesis that the factors selected affect the probability of default.

We may receive fair critique here that our model could be extended. This is true. For instance, we could have accounted for company size as the logarithm of total assets, as done by Ermolova and Penikas (2017) and Lozinskaia et al. (2017), or we could have considered the non-linear dependencies by adding squared terms, as done by Ermolova and Penikas (2017). We could have used alternative indicators, such as net payables or wage-related expenses. The former is partially accounted for by our activity indicator. Inclusion of the latter greatly reduces the data sample 
due to missing data. Data on the currency composition of balance sheets is not available in SPARK.

We preserve the baseline setting of the ten-year old Moody's model created by Dwyer et al. (2010) due to its simplicity. Note that our objective is to study the value gained from using a delinquency-based PD model versus using prudential reserve requirements in default predictions given the chosen Moody's model framework. It is, of course, possible to investigate such implications with respect to another baseline model. However, due to the considerable time costs, we prefer to focus on this particular model. For reference, we have already come across situations in which researchers do not build the best possible model, but merely stop with the first they derive (see Zhivaikina and Peresetsky, 2017, p. 56, footnote 7). They precisely state the following: '... Developing the best [PD] model is not within our research scope. In comparison with them, we go further. We wish to explain a greater proportion of the variance of the dependent variable.

This is why we do not stop with our first model, but also add double and triple interactions, although we agree that these make reading the output of the model more complicated.

Having both the independent and dependent variables at hand, we undertake a single-factor analysis consisting of the following statistical procedures.

1) Testing for the variables' discriminatory power. This includes estimating pairwise correlation between the default indicator and the independent variable of interest and its statistical significance.

The correlation matrix is presented in Table B4 (Appendix B). The results provide information about the collinearity among the ratios selected. We see from Table B4 that the suggested variables are significant and have the expected signs, except for the leverage ratios, which may be explained by the heterogeneity of the high- and low-leverage groups.

2) Visual analysis via scatter plot of the independent variables against the dependent variable or against the default rate. The latter is done in the work by the Bank of Japan (2019).

Pairwise representation demonstrates the relationship between the average ratios and default rates across industries and leverage levels. For example, Figure 3 demonstrates the industry-level relationship between the activity ratio and default rates for the high- and low-leverage groups. It shows strong, significant dependence, because the default rate is much higher for higher-leveraged companies than for lower-leveraged ones.

For a detailed visual representation of the relationship between the default rate and the independent variables at the industry level for different leverage groups, see Appendix B. There, we present a visual representation equivalent to that in Figure 3 to obtain an initial idea as to whether we should use linear or quadratic dependence as the indicator of interest in the regression model. If the linear trend significantly deviates from its quadratic counterpart, then the quadratic relationship should be 
preferred, as in Ermolova and Penikas (2017, p. 343) with the squared ratio of fixed assets to total liabilities.

\subsection{Alternative indicators}

Below, we report the descriptive statistics for the alternative credit risk indicators (credit quality groups or prudential reserve ratios and credit spreads) for the companies which are available from the credit registry (confidential supervisory dataset of all loans offered in Russia to corporate borrowers; banks report this information on form No. 0409303). Their distribution frequencies are available in Figures 4 and 5, respectively.

Table 4. Descriptive statistics

\begin{tabular}{|c|c|c|c|c|c|}
\hline Variable & Default mark & Mean & $\begin{array}{l}\text { Standard } \\
\text { deviation }\end{array}$ & Min & $\operatorname{Max}$ \\
\hline \multirow[t]{2}{*}{ Credit Spread } & Default & 14.304 & 4.834 & 0 & 50 \\
\hline & Non-default & 12.731 & 3.665 & 0 & 68.44 \\
\hline
\end{tabular}

Source: authors' calculations

Figure 4. Loan quality groups distribution

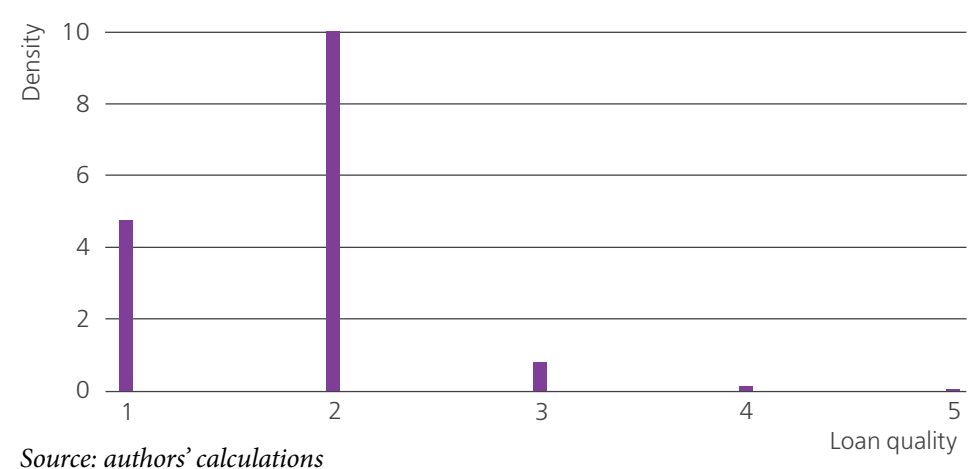

Figure 5. Credit spread distribution

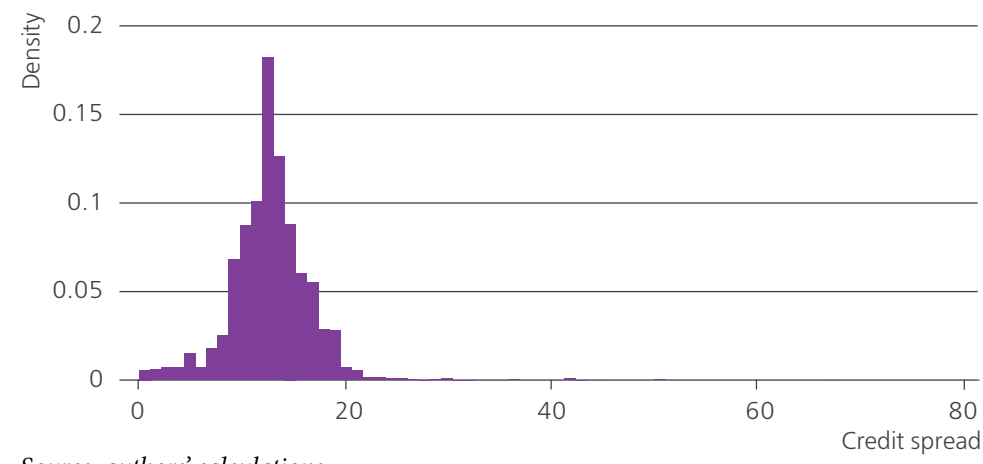

Source: authors' calculations 


\section{Empirical findings}

\subsection{Univariate PD model}

Table 5 presents the results of the simplest (univariate) PD model. We have obtained coefficients consistent with previous research. However, we can compare our findings perfectly only with the Moody's research of Korableva (2011), while for other similar research we have to interpret comparable indicators. Nevertheless, we confirm similar factors affecting the probability of defaults, as can be seen from the comparison of the signs of the coefficients in Table 5. A higher activity proxy generally implies a higher PD. Oppositely, PD is higher when three other indicators are lower. These are the debt coverage ratio, liquidity, and profitability (ROA). The growth and leverage proxies demonstrate more complicated dependences. To capture these, we further add double and triple interactions, which we explain below.

\subsection{Baseline PD model}

Tables 6-8 contain the regression results for our model (see Figure 6). Interested readers may, thus, reconstruct the model with the coefficients mentioned below and run it for their own benefit. For illustration, see the upper-left cell of Table 8 (Activity, Industry $2 \times$ Leverage). It has a coefficient of 0.0046 which is significant at $1 \%$. We see Activity in the first row and Industry 2 multiplied by Leverage in the first column. This means that $X^{\prime} \beta$ in equation 1 is calculated in this case as:

\section{$0.0046 \times$ Activity $\times$ Industry $2 \times$ Leverage,}

where Activity is the ratio of accounts payable to sales (see Table B1 in Appendix B). Industry 2 is a dummy variable that equals one if the enterprise is in the Forestry and Agriculture sector and otherwise equals zero (see the caption to Figure 3). Leverage is another dummy variable that takes a value of one if $\left(1-L E V \_E Q\right)$ exceeds the median value for the given industry.

We will not discuss every regression coefficient, nor their marginal effects, due to the complexities arising from the use of double and triple interactions. We consider the interpretation we gave above for the univariate dependence to be sufficient.

\subsection{Alternative measures of ex ante credit risk}

We have developed the PD model as a measure of ex ante credit risk at a horizon of one year. We are now able to apply the model in (pseudo-) real time, i.e. to estimate the ex ante credit risk for every new loan issued by a bank in a given time period. 
Table 5. Analysis of univariate regression

\begin{tabular}{|c|c|c|c|c|c|c|}
\hline \multirow[b]{2}{*}{ No. } & \multirow[b]{2}{*}{ Variable } & \multirow[b]{2}{*}{$\begin{array}{l}\text { Coeffficient } \\
\text { (standard } \\
\text { error) }\end{array}$} & \multirow[b]{2}{*}{$\begin{array}{l}\text { Pseudo } \\
\mathbf{R}^{2}\end{array}$} & \multicolumn{3}{|c|}{ Signs in previous models } \\
\hline & & & & $\begin{array}{l}\text { Korableva } \\
(2011, \\
\text { p. 56) }\end{array}$ & $\begin{array}{l}\text { Ermolova and Penikas } \\
(2017)\end{array}$ & Mogilat (2019) \\
\hline 1 & Activity & $\begin{array}{l}0.014^{* * *} \\
(0.000)\end{array}$ & 0.004 & + & $\begin{array}{l}+ \\
\text { (indicator of positive } \\
\text { profit, binary variable) }\end{array}$ & $\begin{array}{l}\text { - } \\
\text { (working capital } \\
\text { turnover) }\end{array}$ \\
\hline 2 & Debtcover & $\begin{array}{l}-0.059^{* * *} \\
(0.001)\end{array}$ & 0.003 & - & $\begin{array}{l}- \\
\text { (capital to accounts } \\
\text { payable) } \\
+ \\
\text { (logarithm of accounts } \\
\text { receivable to debt) }\end{array}$ & $\begin{array}{l}- \\
\text { (profit before tax to debt) } \\
+ \\
\text { (net debt to assets) }\end{array}$ \\
\hline 3 & Growth & $\begin{array}{l}-2.632^{* * *} \\
(0.009)\end{array}$ & 0.020 & $\mathrm{U}$ & - & - \\
\hline 4 & $L E V_{-} E Q$ & $\begin{array}{l}-0.252^{* * *} \\
(0.001)\end{array}$ & 0.012 & $+/-$ & $\stackrel{+}{\text { (working capital }}$ & $\mathrm{n} / \mathrm{a}$ \\
\hline 5 & $L E V_{-} R E$ & $\begin{array}{l}-0.011^{* * *} \\
(0.000)\end{array}$ & 0.001 & $+/-$ & to total assets) & $\mathrm{n} / \mathrm{a}$ \\
\hline 6 & Liquidity & $\begin{array}{l}-1.432^{* * *} \\
(0.008)\end{array}$ & 0.009 & - & $\begin{array}{l}\text { (cash flow to total assets) } \\
\text {. }\end{array}$ & - \\
\hline 7 & $R O A$ & $\begin{array}{l}-0.452^{* * *} \\
(0.003)\end{array}$ & 0.005 & - & $\begin{array}{l}\text { - } \\
\text { (sales to total assets) }\end{array}$ & - \\
\hline
\end{tabular}

Note: Standard errors in parentheses; ${ }^{*} \mathrm{p}<0.10,{ }^{* *} \mathrm{p}<0.05,{ }^{* * *} \mathrm{p}<0.01$; total number of observations: 12,938,679. The intercept is not included, though it equals around $-1.6^{* * *} ; \mathrm{n} / \mathrm{a}-$ not applicable. See the descriptions of the variables in Table B1 and Table B2 in Appendix B. U denotes a U-shaped dependence, when there is a break in pattern (before the break point the dependence might be positive and later negative, or inversely); $+/$ - stands for the situation when the dependence is not robustly identified (in one specification it occurs with positive sign and in other - with the negative one).

Source: authors' calculations

Table 6. Regression results

\begin{tabular}{|c|c|c|c|}
\hline Variables & Model 1 & Variables & Model 1 \\
\hline Activity & $\begin{array}{l}-\mathbf{0 . 0 0 0 1} \\
(0.0001)\end{array}$ & Industry4 & $\begin{array}{l}-\mathbf{0 . 1 1 7 8} \\
(0.0055)\end{array}$ \\
\hline Debtcover & $\begin{array}{l}-\mathbf{- 0 . 0 0 0 2}^{*} \\
(0.001)\end{array}$ & Industry5 & $\begin{array}{l}-\mathbf{- 0 . 0 3 0 9} \\
(0.0207)\end{array}$ \\
\hline Growth & $\begin{array}{l}-\mathbf{0 . 9 3 4 3} \\
(0.0124)\end{array}$ & Industry 6 & $\begin{array}{l}-\mathbf{0 . 2 3 1 5} \\
(0.0048)\end{array}$ \\
\hline$L E V_{-} E Q$ & $\begin{array}{l}\mathbf{0 . 0 0 0 1} \\
(0.0001)\end{array}$ & Industry 7 & $\begin{array}{l}-\mathbf{0 . 0 2 8 9}^{* * *} \\
(0.0063)\end{array}$ \\
\hline$L E V_{-} R E$ & $\begin{array}{l}-\mathbf{0 . 0 0 0 1} 1^{* * *} \\
(0.0000)\end{array}$ & Industry8 & $\begin{array}{l}-\mathbf{0 . 1 1 3 1} 1^{* * *} \\
(0.0136)\end{array}$ \\
\hline Industry 2 & $\begin{array}{l}\mathbf{0 . 1 0 3 6}^{* * *} \\
(0.0065)\end{array}$ & Industry 9 & $\begin{array}{l}-\mathbf{0 . 1 3 7 1} 1^{* * *} \\
(0.0039)\end{array}$ \\
\hline Industry3 & $\begin{array}{l}\mathbf{0 . 1 2 2 0}^{* * *} \\
(0.0081)\end{array}$ & Leverage dummy & $\begin{array}{l}\mathbf{0 . 6 2 7 0}^{* * *} \\
(0.0047)\end{array}$ \\
\hline Intercept & $\begin{array}{l}-\mathbf{1 . 9 0 7 1} \mathbf{1}^{* * *} \\
(0.0033)\end{array}$ & & \\
\hline Observations & $10,826,964$ & & \\
\hline Pseudo $\mathrm{R}^{2}$ & 0.0664 & & \\
\hline Area under ROC curve (training sample) & 0.7248 & & \\
\hline Area under ROC curve (test sapple) & 0.7244 & & \\
\hline
\end{tabular}

Note: Standard errors in parentheses; ${ }^{\star} \mathrm{p}<0.10,{ }^{* *} \mathrm{p}<0.05,{ }^{* * *} \mathrm{p}<0.01$.

Source: authors' calculations 
Table 7. Regression results (cont.): double interaction terms

\begin{tabular}{llllllllllll} 
Variables & Industry2 & Industry3 & Industry4 & Industry5 & Industry6 & Industry7 & Industry8 & Industry9 & Leverage \\
\hline Leverage & -0.0034 & $-0.3477^{* * *}$ & $-0.0976^{* * *}$ & $-0.0753^{* * *}$ & $-0.1731^{* * *}$ & $-0.1393^{* * *}$ & $-0.2171^{* * *}$ & $-0.0986^{* * *}$ & \\
& $(0.0085)$ & $(0.0111)$ & $(0.0072)$ & $(0.0245)$ & $(0.0067)$ & $(0.0085)$ & $(0.0198)$ & $(0.0055)$ & \\
\hline Activity & $7.18 \mathrm{E}-06^{* * *}-1.75 \mathrm{E}-06$ & $5.59 \mathrm{E}-08$ & -0.0001 & $-2.89 \mathrm{E}-08$ & $8.21 \mathrm{E}-06^{* * *}$ & $0.00001^{* *}$ & $7.15 \mathrm{e}-08$ & $0.0055^{* * *}$ \\
& $(0.0000)$ & $(0.000)$ & $(0.000)$ & $(0.000)$ & $(0.000)$ & $(0.000)$ & $(0.000)$ & $(0.000)$ & $(0.0004)$ \\
\hline Debtcover & $0.0002^{* * *}$ & $0.0002^{* * *}$ & 0.0001 & -0.0002 & $0.0002^{* * *}$ & $0.0003^{* * *}$ & $0.0049^{* * *}$ & $0.0002^{* * *}$ & $0.0387^{* * *}$ \\
& $(0.0001)$ & $(0.0001)$ & $(0.0001)$ & $(0.0071)$ & $(0.0001)$ & $(0.0001)$ & $(0.0001)$ & $(0.0001)$ & $(0.0083)$ \\
\hline Growth & $0.5439^{* * *}$ & $0.1334^{* * *}$ & $-0.3550^{* * *}$ & 0.0821 & $0.0682^{* * *}$ & $-0.4358^{* * *}$ & $0.9341^{* * *}$ & $0.8335^{* * *}$ & $-1.5812^{* * *}$ \\
& $(0.0196)$ & $(0.0248)$ & $(0.0212)$ & $(0.1221)$ & $(0.0231)$ & $(0.0336)$ & $(0.0130)$ & $(0.0125)$ & $(0.0337)$ \\
\hline LEV_EQ & $-0.0003^{* * *}$ & $-2.12 \mathrm{E}-06$ & $3.16 \mathrm{E}-07$ & 0.0002 & - & $-0.00003^{* * *}-0.0005$ & $-0.00002^{* * *}-0.2001^{* * *}$ \\
& $(0.0001)$ & $(0.0000)$ & $(0.0000)$ & $(0.0027)$ & & $(0.0000)$ & $(0.0005)$ & $(0.0000)$ & $(0.0050)$ \\
\hline LEV_RE & $0.0001^{* * *}$ & $0.0001^{* * *}$ & 0.0001 & $-0.0010^{* * *}$ & $0.0001^{* * *}$ & $0.0001^{* * *}$ & $-0.0007^{* * *}$ & $0.0001^{* * *}$ & $0.0040^{* * *}$ \\
& $(0.0000)$ & $(0.0001)$ & $(0.0000)$ & $(0.0002)$ & $(0.0000)$ & $(0.0000)$ & $(0.0002)$ & $(0.0000)$ & $(0.0013)$ \\
\hline Liquidity & $-0.9426^{* * *}$ & $0.0668^{* * *}$ & $-0.5229^{* * *}$ & $-1.3228^{* * *}-$ & $-0.0211^{*}$ & $-3.2495^{* * *}$ & $-0.0556^{* * *}$ & $-1.7242^{* * *}$ \\
& $(0.0598)$ & $(0.0199)$ & $(0.0296)$ & $(0.2306)$ & & $(0.0125)$ & $(0.2259)$ & $(0.0028)$ & $(0.0331)$ \\
\hline ROA & $0.0008^{* * *}$ & $0.0002^{* * *}$ & $-0.0003^{* * *}$ & $-0.7540^{* * *}-$ & $0.0004^{* * *}$ & $-0.0645^{* * *}$ & 0.000 & $-0.3143^{* * *}$ \\
& $(0.0003)$ & $(0.0001)$ & $(0.0001)$ & $(0.0026)$ & & $(0.0001)$ & $(0.0021)$ & $(0.000)$ & $(0.0196)$ \\
\hline
\end{tabular}

Note: Standard errors in parentheses; ${ }^{*} \mathrm{p}<0.10,{ }^{* *} \mathrm{p}<0.05,{ }^{* * *} \mathrm{p}<0.01$.

Source: authors' calculations

Table 8. Regression results (cont.): triple interaction terms

\begin{tabular}{|c|c|c|c|c|c|c|c|c|}
\hline Variables & $\begin{array}{l}\text { Industry } 2 \times \\
\text { Leverage }\end{array}$ & $\begin{array}{l}\text { Industry } 3 \times \\
\text { Leverage }\end{array}$ & $\begin{array}{l}\text { Industry } 4 \times \\
\text { Leverage }\end{array}$ & $\begin{array}{l}\text { Industry } 5 \times \\
\text { Leverage }\end{array}$ & $\begin{array}{l}\text { Industry } 6 \times \\
\text { Leverage }\end{array}$ & $\begin{array}{l}\text { Industry } 7 \times \\
\text { Leverage }\end{array}$ & $\begin{array}{l}\text { Industry } 8 \times \\
\text { Leverage }\end{array}$ & $\begin{array}{l}\text { Industry } 9 \times \\
\text { Leverage }\end{array}$ \\
\hline tivity & $\begin{array}{l}0.0046^{* * *} \\
(0.0006)\end{array}$ & $\begin{array}{l}0.0038^{* * *} \\
(0.0012)\end{array}$ & $\begin{array}{l}0.0061^{* * *} \\
(0.0006)\end{array}$ & & & $\begin{array}{l}0.0044^{* * *} \\
(0.0009)\end{array}$ & & $\begin{array}{l}0.0044^{* * *} \\
(0.0005)\end{array}$ \\
\hline Debtcover & $\begin{array}{l}-0.0408^{* * *} \\
(0.0157)\end{array}$ & $\begin{array}{l}-0.0418^{* * *} \\
(0.0149)\end{array}$ & $\begin{array}{l}0.1286^{* * *} \\
(0.0117)\end{array}$ & & & & & $\begin{array}{l}0.1228^{* * *} \\
(0.0093)\end{array}$ \\
\hline Growth & $\begin{array}{l}-1.0482^{* * *} \\
(0.0612)\end{array}$ & $\begin{array}{l}-0.6373^{* * *} \\
(0.0888)\end{array}$ & $\begin{array}{l}-0.3429^{* * *} \\
(0.0517)\end{array}$ & $\begin{array}{l}-0.4356^{* * *} \\
(0.1868)\end{array}$ & $\begin{array}{l}0.2859^{* * *} \\
(0.0509)\end{array}$ & & $\begin{array}{l}-1.3369^{* * *} \\
(0.1706)\end{array}$ & $\begin{array}{l}-1.6705^{* * *} \\
(0.0389)\end{array}$ \\
\hline$L E V_{-} E Q$ & $\begin{array}{l}0.0141^{*} \\
(0.0074)\end{array}$ & $\begin{array}{l}0.1325^{* * *} \\
(0.0080)\end{array}$ & $\begin{array}{l}-0.0026 \\
(0.0065)\end{array}$ & $\begin{array}{l}-0.0402^{* *} \\
(0.0186)\end{array}$ & $\begin{array}{l}0.0695^{* * *} \\
(0.0060)\end{array}$ & $\begin{array}{l}0.0367^{* * *} \\
(0.0075)\end{array}$ & $\begin{array}{l}-0.0358^{* * *} \\
(0.0151)\end{array}$ & $\begin{array}{l}-0.0529^{* * *} \\
(0.0057)\end{array}$ \\
\hline$L E V_{-} R E$ & $\begin{array}{l}-1.0165^{* * *} \\
(0.0015)\end{array}$ & $\begin{array}{l}-0.0050^{* * *} \\
(0.0018)\end{array}$ & $\begin{array}{l}-0.0203^{* * *} \\
(0.0022)\end{array}$ & $\begin{array}{l}-0.0358^{* * *} \\
(0.0113)\end{array}$ & $\begin{array}{l}-0.0130^{* * *} \\
(0.0015)\end{array}$ & $\begin{array}{l}-0.0090^{* * *} \\
(0.0018)\end{array}$ & $\begin{array}{l}-0.0562^{* * *} \\
(0.0110)\end{array}$ & $\begin{array}{l}0.0009 \\
(0.0014)\end{array}$ \\
\hline Liquidity & $\begin{array}{l}0.3120^{* * *} \\
(0.1116)\end{array}$ & $\begin{array}{l}0.6478^{* * *} \\
(0.0796)\end{array}$ & $\begin{array}{l}0.5667^{* * *} \\
(0.0647)\end{array}$ & $\begin{array}{l}1.5466^{\star * *} \\
(0.3121)\end{array}$ & $\begin{array}{l}0.4121^{\star * *} \\
(0.0494)\end{array}$ & $\begin{array}{l}0.2526^{* * *} \\
(0.0654)\end{array}$ & $\begin{array}{l}1.8746^{* * *} \\
(0.3491)\end{array}$ & $\begin{array}{l}0.2823^{* * *} \\
(0.0404)\end{array}$ \\
\hline$R O A$ & $\begin{array}{l}-0.2853^{\star * *} \\
(0.0386)\end{array}$ & $\begin{array}{l}0.2418^{* * *} \\
(0.0287)\end{array}$ & $\begin{array}{l}-0.1772^{* * *} \\
(0.0270)\end{array}$ & $\begin{array}{l}0.1665^{*} \\
(0.0870)\end{array}$ & $\begin{array}{l}0.1141^{* * *} \\
(0.0239)\end{array}$ & $\begin{array}{l}0.1630^{* * *} \\
(0.0294)\end{array}$ & $\begin{array}{l}-0.0546 \\
(0.0707)\end{array}$ & $\begin{array}{l}-0.0545^{\star *} \\
(0.0222)\end{array}$ \\
\hline
\end{tabular}

Note: Standard errors in parentheses; ${ }^{*} \mathrm{p}<0.10,{ }^{* *} \mathrm{p}<0.05,{ }^{* * *} \mathrm{p}<0.01$.

Source: authors' calculations

We compare the performance of the alternative measures of ex ante credit risk in terms of their forecast of ex-post credit discipline. We run probit regression (in line with formula (1)) with credit quality groups or credit spreads in interest rates as independent variables. In the case of regression with credit spreads, we also control for the characteristics of the loans (maturity of loans issued). We make the preliminary assumption that the credit quality group reflects the creditworthiness of the borrower, and that the credit spread in the interest rate reflects the borrower's inherent risk. In line with the construction of the PD model, we define three specifications for alternative measures of ex ante credit risk: Model 1 (CQG) and Model 1 (CS) contain only independent variables (quality group or credit spread, 
respectively), Model 2 (CQG) and Model 2 (CS) include control variables for industry and leverage groups, and Model 3 (CQG) and Model 3 (CS) additionally contain interaction terms. We use a random 80/20 division to construct training and test subsets. Our dataset is not balanced in terms of the number of observations in the default and non-default groups. In this case, it is more appropriate to use the F1 score to compare the performance of all alternative ex ante credit risk measures (Shibitov and Mamedli, 2019). The F1 score takes into account information concerning the predictions for the default and non-default groups of companies. Figure 7 presents the results. The PD model produced a higher F1 score than the alternative measures (see Figure 7).

Figure 6. F1 score evolution for different threshold levels and model specifications

A) PD model

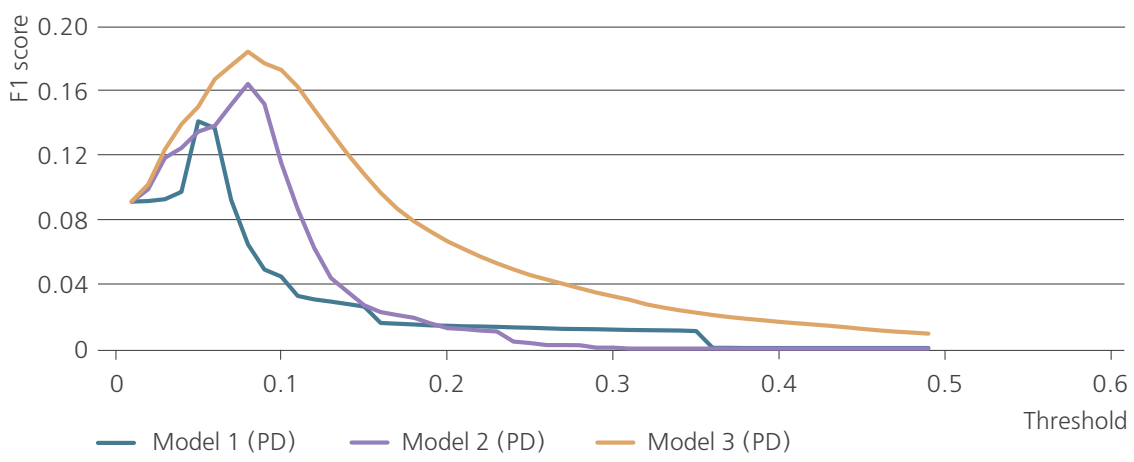

B) CQG, CS

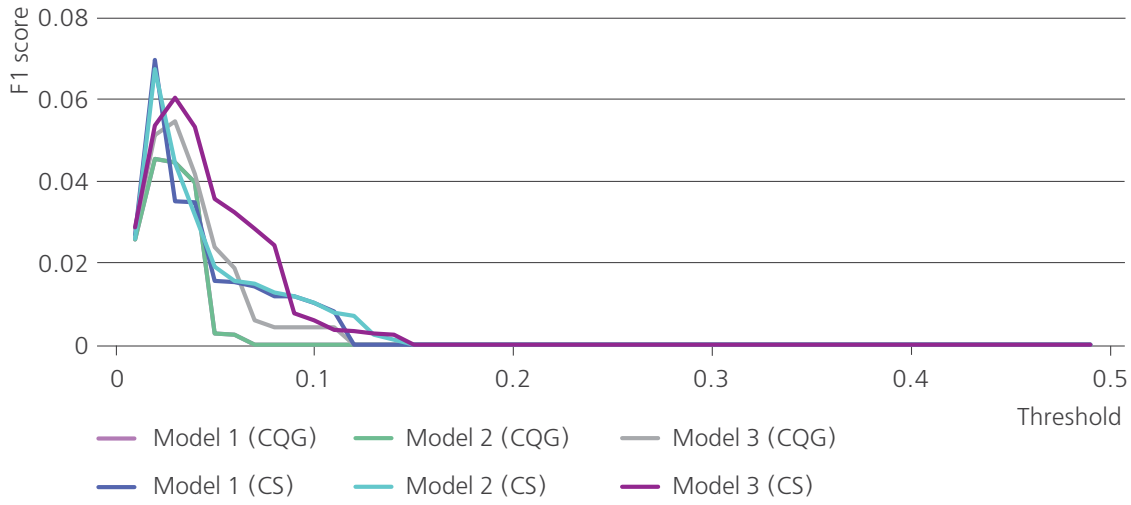

Note: Model 1 - baseline specification with the shortest list of independent variables (matches the specification by Moody's; see Table 6); Model 2 - extended specification where we add industry and leverage dummies (see Tables 6-7); Model 3 - the full specification where Model 2 is enhanced by interaction of industry and leverage dummies (see Tables 6-8). PD - specification where $Y$ is the default flag (it may equal to zero or one); CQG specification where the dependent $Y$ variables is another discrete variable - the quality category (it is an ordered variable ranging from one to five); $\mathrm{CS}$ - specification with the floating dependent variable of the credit spread. 
Figure 7. F1 score evolution for different threshold levels and alternative measures of ex ante credit risk

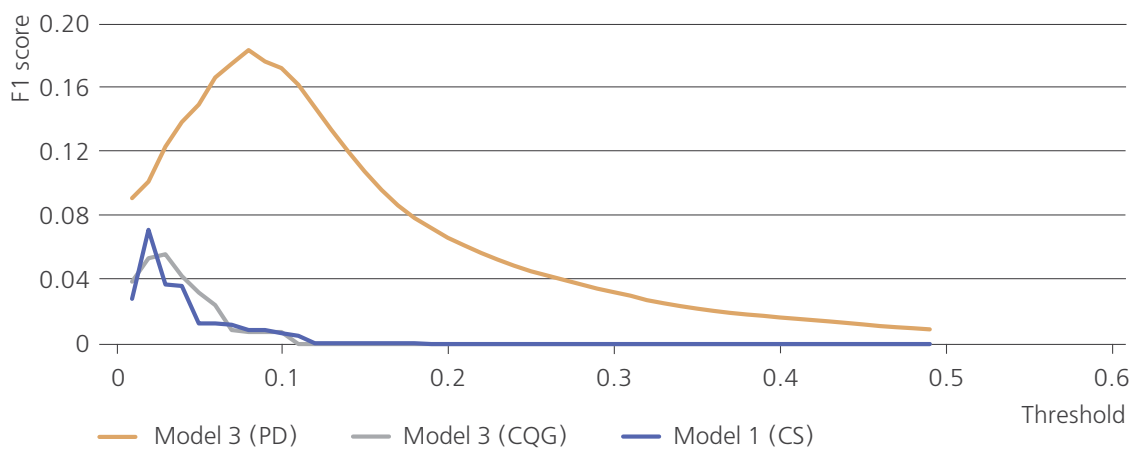

Source: authors' calculations

\subsection{Regression output tests}

We perform the following tests for Model 3 (the model specification containing dummy and interaction terms for industry and leverage level (see Table 9)).

1) Overall goodness-of-fit testing (we reject models with low or negative adjusted $R^{2}$ values. We also run Pearson test for goodness-of-fit, which is the sum of the differences between the observed and expected outcome frequencies, each squared and divided by the expectation. The resulting statistical value can be compared with a $\chi^{2}$ distribution).

2) Significance and economic adequacy of regressors (we need the coefficients of the variables to be statistically significant (i.e. not equal to zero) at the $10 \%$ confidence value at least and have the expected sign).

3) Normality of model residuals (we run a Shapiro-Wilk test to test the distribution of the model residuals).

4) Model specification tests (we run link and Ramsey tests to check whether the linear model is sufficient compared to the non-linear (logarithmic) one and whether there are any omitted (squared) variables). The link test adds a squared independent variable to the model and tests for significance compared to the non-squared model. A model without a link error will have a nonsignificant t-test when compared with the unsquared version.

Table 9. Regression output tests

\begin{tabular}{lll} 
Normality of residuals & & \\
\hline Shapiro-Wilk & stat & $1.8 \mathrm{E}-234$ \\
& p-value & $32.67 \%$ \\
Model specification tests & & 2876.56 \\
\hline Ramsey & stat & $0 \%$ \\
\hline Link test & p-value & 480.52 \\
& stat & $0 \%$
\end{tabular}




\section{Policy implications}

The PD model developed in this paper is unique for Russian data on corporate loans. It is novel in that it predicts default, and not bankruptcy. Thus, it may be useful in two ways in the day-to-day operations of commercial banks and of the central bank. These uses are:

1) Benchmarking for IFRS 9 and IRB from Basel III (for discussion of IRB, see Penikas 2015, 2020a);

2) Outsourcing of risk estimation for small banks.

Benchmarking allows the use of the PD model developed to compare a bank's internal risk estimates to those of the model. This may be more useful and desirable to larger banks. There are two domains in particular that require risk estimation and further use in prudential regulation. These are loan loss provisioning in accordance with IFRS 9 and the derivation of capital requirements using the Internal-RatingsBased (IRB) approach of Basel II and Basel III. The supervisory unit of the Bank of Russia may use the PD model developed as a conservative tool. In cases where the model delivers a higher risk estimate, the supervisor may wish to request that a bank increase its provisioning rate for a particular borrower. When conducting IRB validation, the PD model developed may also act as a sanity check for the accuracy of a bank's risk prediction.

There is another prospective use for the PD model developed. Here we wish to recall the practice of developed countries such as the United States. They outsource risk estimation functions from commercial banks to the central bank. This helps smalland medium-sized banks to cut the costs of data collection and the development and maintenance of PD models. Thus, commercial bank can focus solely on the selection of clients based on the risk (PD) estimates obtained per client. As a result, such cost optimisation may allow smaller banks to offer better loan rates and compete with the larger players in certain niches, such as, for instance, SME lending. Such a project was already piloted by the Bank of Russia and the Association of Russian Banks in 20182019. It showed that there is a list of legal issues that the supervisor must consider for this to be a viable option in the industry. The supervisor must also decide whether PD estimates derived from the common model should be used as they are or whether they are merely proxies presenting possible options for banks' final decisions. The supervisor must determine whether it is ready to bear the cost in the event of the borrower insolvency upon the prediction of low credit risk from the model. These issues are important. However, the model developed suggests that at least half of the work has been done, and the PD module has been developed and calibrated. Whether a PD outsourcing project will be launched on the basis of this or an equivalent model is a topic for a separate discussion.

Appendices are available at

http://rjmf.econs.online/en; doi.org/10.31477/rjmf.202103.49 


\section{References}

Altman, E. (1968). Financial Ratios, Discriminant Analysis and the Prediction of Corporate Bankruptcy. The Journal of Finance, 23(4), pp. 589-609.

https://doi.org/10.1111/j.1540-6261.1968.tb00843.x

Altman, E. and Sabato, G. (2003). Modeling Credit Risk for SMEs: Evidence from the US Market. http://people.stern.nyu.edu/ealtman/ModelingCreditRiskforSMEs\%20.pdf [accessed on 16 August 2021].

Andrikopoulos, P. and Khorasgani, A. (2018). Predicting Unlisted SMEs' Default: Incorporating Market Information on Accounting-Based Models for Improved. British Accounting Review, 50(5), pp. 559-573. https://doi.org/10.1016/j.bar.2018.02.003

Bank of Japan (2019). A Forecast Model for the Probability of Default Based on Granular Firm-Level Data and Its Application to Stress Testing. BOJ Reports and Research Papers.

Basel Committee on Banking Supervision (2000). Principles for the Management of Credit Risk.

Basel Committee on Banking Supervision (2005). Studies on the Validation on Internal Rating Systems. Basel Committee on Banking Supervision Working Paper, N 14.

Basel Committee on Banking Supervision (2006). Basel II: International Convergence of Capital Measurement and Capital Standards: A Revised FrameworkComprehensive Version.

Basel Committee on Banking Supervision (2017). Basel III: Finalising Post-Crisis Reforms.

Beaver, W. H. (1966). Financial Ratios as Predictors of Failure. Journal of Accounting Research, 4, pp. 71-111. https://doi.org/10.2307/2490171

Berskon, J. (1944). Application of the Logistic Function to Bio-Assay. Journal of the American Statistical Association, 39(227), pp. 357-365. https://doi.org/10.1080/01621459.1944.10500699

Bliss, C. I. (1934). The Method of Probits. Science, 79(2037), pp. 38-39. https://doi.org/10.1126/science.79.2037.38

Borio, C. and Zhu, H. (2008). Risk-Taking: A Missing Link in the Transmission Mechanism? BIS Working Papers, N 268.

Bruno, V. and Shin, H. S. (2012). Capital Flows and the Risk-Taking Channel of Monetary Policy. BIS Working Papers, N 400.

Burova, A., Penikas, H., Ponomarenko, A., Popova, S., Sinyakov, A. and Ushakova, Y. (2020). Measuring the Risk-Taking of Russian Banks: Micro-level Data Approach. Presentation. http://cbr.ru/Content/Document/File/115876/Measuring\%20the\%20 Risk-taking\%20of\%20Russian\%20Banks_Micro-level\%20data\%20approach_ Sinyakov.pdf [accessed on 16 August 2021].

Cameron, A. C. and Trivedi, P. K. (2010). Microeconometrics Using Stata, revised ed. Stata Press.

Cecchetti, S. G. and Li, L. (2005). Do Capital Adequacy Requirements Matter for Monetary Policy? NBER Working Paper, N 11830. https://doi.org/10.3386/w11830 
Delis, M. D., Hasan, I. and Mylonidis, N. (2017). The Risk-Taking Channel of Monetary Policy in the U.S.: Evidence from Corporate Loan Data. Journal of Money, Credit and Banking, 49(1), pp. 187-213. https://doi.org/10.1111/jmcb.12372

Dell'Ariccia, G., Laeven, L. and Suarez, G. A. (2017). Bank Leverage and Monetary Policy's Risk-Taking Channel: Evidence from the United States. Journal of Finance, 72(2), pp. 613-654. https://doi.org/10.1111/jofi.12467

Dwyer, D., Kocagil, A. and Stein, R. (2004). Moody's KMV RiskCalc v3.1 Model: NextGeneration Technology for Predicting Private Firm Credit Risk.

Dwyer, D., Korableva, I. and Zhao, J. (2010). Moody's KMV RiskCalc V3.1 Russia Model. [In Russian].

Ermolova, M. and Penikas, H. (2017). PD-LGD Correlation Study: Evidence from the Russian Corporate Bond Market. Model Assisted Statistics and Applications, 12(4), pp. 335-358. https://doi.org/10.3233/MAS-170408

Fantazzini, D. and Figini, S. (2009). Random Survival Forests Models for SME Credit Risk Measurement. Methodology and Computing in Applied Probability, 11(1), pp. 29-45. https://doi.org/10.1007/s11009-008-9078-2

Gupta, J., Barzotto, M. and Khorasgani, A. (2018). Does Size Matter in Predicting SMEs Failure? International Journal of Finance and Economics, 23(4), pp. 571-605. https://doi.org/10.1002/ijfe.1638

Ioannidou, V. P. and Penas, M. F. (2010). Deposit Insurance and Bank Risk-Taking: Evidence from Internal Loan Ratings. Journal of Financial Intermediation, 19(1), pp. 95-115. https://doi.org/10.1016/j.jfi.2009.01.002

Karminsky, A. (2015). Credit Ratings and Their Modelling. Moscow: HSE Publishing House. [In Russian].

Korableva, I. (2011). Izmereniye riska defolta chastnykh rossiyskikh kompaniy s pomoshchyu modeley Moody's Analytics RiskCalc [Measuring the Default Risk of Private Russian Companies Using Moody's Analytics RiskCalc Models]. Analiticheskiy bankovskiy zhurnal, 3(189), pp. 54-65. [In Russian].

Lozinskaia, A., Merikas, A., Merika, A. and Penikas, H. (2017). Determinants of the Probability of Default: The Case of the Internationally Listed Shipping Corporations. Maritime Policy and Management, 44(7), pp. 837-858. https://doi.org/10.1080/03088839.2017.1345018

Luppi, B., Marzo, M. and Scorcu, A. E. (2007). A Credit Risk Model for Italian SMEs. Universita di Bologna, Dipartimento di Scienze Economiche (DSE) Working Paper, N 600. https://doi.org/10.6092/unibo/amsacta/4674

Miteski, M., Mitreska, A. and Vaskov, M. (2018). The Risk-Taking Channel of Monetary Policy in Macedonia: Evidence from Credit Registry Data. National Bank of the Republic of Macedonia Working Paper, N 7.

Mogilat, A. (2015). Bankrotstvo kompaniy real'nogo sektora $v$ Rossii: tendentsii, strukturnyye kharakteristiki i osnovnyye factory [Bankruptcy of Real Sector Companies in Russia: Trends, Structural Characteristics and Main Factors]. Presentation. [In Russian]. http://www.forecast.ru/_ARCHIVE/Presentations/ HSE/2015/bank042015.pdf [accessed on 16 August 2021]. 
Mogilat, A. N. (2019). Modelling Financial Distress of Russian Industrial Companies, or What Bankruptcy Analysis Can Tell. Voprosy Ekonomiki, 3, pp. 101-118. [In Russian]. https://doi.org/10.32609/0042-8736-2019-3-101-118

Ozdemir, B. and Miu, P. (2008). Basel II Implementation. A Guide to Developing and Validating a Compliant Internal Risk Rating System. New York: McGraw-Hill.

Paligorova, T. and Santos, J. A. C. (2017). Monetary Policy and Bank Risk-Taking: Evidence from the Corporate Loan Market. Journal of Financial Intermediation, 30, pp. 35-49. https://doi.org/10.1016/j.jfi.2016.11.003

Penikas, H. (2013). Vozniknoveniye poter' mertvogo gruza pri ispol'zovanii individual'nykh vnutribankovskikh (IRB) modeley otsenki kreditnogo riska po B azel II [The occurrence of dead weight losses when using IRB credit risk assessment models according to Basel II]. In: Sbornik trudov nauchno-prakticheskoy konferentsii MGIMO 'Ekonometricheskiye metody $v$ issledovanii global'nykh ekonomicheskikh protsessov'. Moscow: Ankil, pp. 149-155.

Penikas, H. (2015). History of Banking Regulation as Developed by the Basel Committee on Banking Supervision in 1974-2014 (Brief Overview). Revista Estabilidad Financiera (Financial Stability Review of the Bank of Spain), 28(5), pp. 9-47.

Penikas, H. (2020a). History of the Basel Internal-Ratings-Based (IRB) Credit Risk Regulation. Model Assisted Statistics and Applications, 15(1), pp. 81-98. https://doi.org/10.3233/MAS-190480

Penikas, H. (2020b). The Review of the Open Challenges in the IRB Loan Portfolio Credit Risk Modeling. Model Assisted Statistics and Applications, 15(4), pp. 371-388. https://doi.org/10.3233/MAS-200508

Pompe, P. and Bilderbeek, J. (2005). The Prediction of Bankruptcy of Small- and Medium-Sized Industrial Firms. Journal of Business Venturing, 20(6), pp. 847-868. https://doi.org/10.1016/j.jbusvent.2004.07.003

Shibitov, D. and Mamedli, M. (2019). The Finer Points of Model Comparison in Machine Learning: Forecasting Based on Russian Banks' Data. Bank of Russia Working Paper Series, N 43. http://cbr.ru/Content/Document/File/87572/wp43_e.pdf [accessed on 16 August 2021].

Surzhko, D. (2014). Approach for Multi-Period PD Calibration for LDP Portfolios. http://vixra.org/pdf/1404.0001v1.pdf [accessed on 16 August 2021].

Totmyanina, K. M. (2014). Assessment the Probability of Default for Corporate Borrowers Given Macroeconomic Situation. Journal of Corporate Finance Research, 8(1), pp. 18-30. [In Russian]. https://doi.org/10.17323/j.jcfr.2073-0438.8.1.2014

Vozzella, P. and Gabbi, G. (2010). Default and Asset Correlation: An Empirical Study for Italian SMEs. https://ssrn.com/abstract=1532222 [accessed on 16 August 2021].

Zhivaikina, A. D. and Peresetsky, A. A. (2017). Russian Bank Credit Ratings and Bank License Withdrawal 2012-2016. Journal of the New Economic Association, 36(4), pp. 49-80. [In Russian]. 